\title{
MANIFESTAÇÕES BUCAIS DECORRENTES DA SÍNDROME DA IMUNODEFICIÊNCIA ADQUIRIDA
}

Bárbara Letícia CIPRIANO, Vanessa Celuppi FURMAN, Francisca Berenice Dias GIL, Ângela FERNANDES, Antonio Adilson Soares de LIMA

A Síndrome da Imunodeficiência Adquirida (AIDS) é uma doença infectocontagiosa, causada pelo retrovírus HIV. A principal célula-alvo do vírus HIV é o linfócito TCD4 auxiliar. Uma característica patológica desse vírus é a diminuição progressiva da imunidade celular e o conseqüente aparecimento de infecções oportunistas e neoplasias malignas. As manifestações bucais da infecção pelo HIV são comuns e podem representar um importante valor diagnóstico da doença. Aproximadamente $60 \%$ dos indivíduos infectados pelo HIV apresentam essas manifestações. Portanto, a presença de alterações bucais sugestivas de imunodepressão deve buscar no paciente a possibilidade de infecção pelo HIV, ou alertar para queda imunológica naqueles que tem a doença. A terapia antiretroviral diminui a carga viral e aumenta as células CD4+, resultando menor freqüência de lesões oportunistas. Quando estas aparecem durante o tratamento podem indicar falha terapêutica. Além da candidíase bucal, as manifestações bucais mais comuns em pacientes soropositivos são a leucoplasia pilosa, periodontite ulcerativa necrosante, herpes simples, herpes zoster e o sarcoma de Kaposi. Outras lesões, menos freqüente observadas são, histoplasmose, linfoma e o carcinoma de células escamosas. Tendo em vista tais aspectos, o presente trabalho tem como objetivo apresentar casos de pacientes HIV positivos internados em hospital apresentando lesões bucais.

Palavras-chave: Infecção; HIV; Candidíase. 